\title{
Citizenship, Naturalization, and Asylum: The Case of Britain
}

\author{
Anthony H. Richmond
}

\begin{abstract}
Citizenship and naturalization procedures in the UK are examined in historical perspective. Recent legislation is reviewed in the light of global change. The implication of membership in the European Union is examined. The differential treatment of Commonwealth citizens and former colonial subjects is reviewed, as well as human rights questions raised by the treatment of asylum seekers. As a result of globalization, Britain is experiencing the same contradictory forces as other advanced industrial societies. Demographic and economic forces promote immigration, which is resisted for a combination of security fears and ethnocentric attitudes.
\end{abstract}

\section{Résumé}

Cet article examine les procédures pour l'obtention de la citoyenneté et de la naturalisation au Royaume Uni dans une perspective historique. À la lumière de changements qui interviennent au niveau global, il passe en revue les lois adoptées récemment. Il examine aussi les implications de l'adhésion du pays à l'Union Européenne. Il passe ensuite en revue le traitement préférentiel accordé aux citoyens des pays du Commonwealth et des anciennes colonies, ainsi que les questions de droits humains soulevées par le traitement réservé aux demandeurs d'asile. La globalisation expose la Grande Bretagne aux mêmes vents contradictoires qui affectent les autres sociétés industrielles avancées. Les forces démographiques et économiques promouvoient l'immigration, alors qu'une combinaison de peurs sécuritaires et d'attitudes ethnocentriques suscite de la résistance.
The combined effects of globalization, the end of the "Cold War," and demographic pressures have given rise to unprecedented population movements in the last decade. When terrorism and security concerns are added to the picture, there is growing pressure to impose strict measures to control admission to advanced industrial countries. The growing number of asylum seekers raises questions of citizenship, naturalization, permission to remain, and the right to work, as well as eligibility for social services, including education, health, and welfare. Nowhere is the consequent crisis more evident than in Britain. Delays in processing asylum applications and tough measures designed to deter so called "economic migrants" raise fundamental issues concerning due process and human rights.

\section{Citizenship and Naturalization}

Britain may be understood as the United Kingdom, including England, Scotland, Wales, and Northern Ireland, but excluding the Channel Islands, former colonies, dependent territories, and independent members of the Commonwealth. Originally, Britain used the term "subject" rather than "citizen." The latter term has its roots in the republican tradition, rather than the monarchical system. Subjects have legal obligations to a sovereign power. Citizens may have obligations, but they also have rights enforceable by law. In some cases they may be able to appeal beyond their own country's courts to a higher authority that has been recognized by treaty. In the case of Britain, this includes the UN, the European Union, and the European Commission on Human Rights, which has a recognized jurisdiction.

Before 1948, all people born in countries that were once part of the British Empire were "British subjects" and had the same legal status. The first legislation using the term "citizenship" was the British Citizenship Act of 1948, which created the status of "Citizen of the United Kingdom and Colonies." Under this Act people from former colonies and self-governing countries of the Commonwealth such as 
Canada, Australia, New Zealand, Ireland, India, and Pakistan could register as Citizens of the UK and Colonies. Granting citizenship by registration was so that an adult citizen of self-governing countries of the Commonwealth, Ireland, and the colonies, who needed to ordinarily reside in the United Kingdom, and had done so for at least twelve months prior to registration, could remain in the country and exercise the franchise, etc. This applied to everyone born in Britain and in British colonies, former colonies, and dominions, whether or not they also had citizenship in their own countries (such as Canada and Australia), or newly independent ones such as India and Pakistan. Initially, this gave the right of entry to and residence in Britain, but this was amended by later immigration legislation.

The Nationality Act of 1981, which came into force in 1983, abolished the category of "Citizen of the United Kingdom and Colonies." Three new categories were created, introducing a significant element of discrimination against former colonial subjects. These were: (a) British citizenship (which applied to those with a close connection with the United Kingdom but not necessarily to everyone born there); (b) British Dependent Territories citizenship (which included Gibraltar and the Falkland Islands); and (c) British Overseas citizenship (which applied to those former citizens of the UK and colonies who had no close connection with the United Kingdom itself). Other categories included British protected persons. Meanwhile, immigration controls had been introduced, so that admission to Britain by former colonial subjects ceased to be a right and became subject to regulation.

The 1981 legislation set out requirements for naturalization. ${ }^{1}$ In summary, each applicant must:

- be aged 18 or over;

- have completed five year's continuous residence

- either meet the "five years residence" requirements or be employed overseas in Crown service under the UK Government;

- be of good character;

- have a sufficient knowledge of the English language (or Welsh or Scottish Gaelic);

- not be of unsound mind; and

- intend, when naturalized, either to live in the UK, or to be employed abroad in Crown service (working directly for Her Majesty's UK Government) or by an international organization of which the UK is a member, or by a company or association established in the UK.

In the year 2000 there were approximately 90,000 applications for citizenship of the UK and over 60,000 decisions. In practice, the process is a bureaucratic one requiring the completion of forms and the payment of fees but, until recently, no formal ceremony. It is also time-consuming, with delays up to twenty months for a decision. Consequently, there have been notorious cases of wealthy individuals, with the right political influence, endeavouring to "jump the queue." The Nationality, Immigration and Asylum Act, 2002 amended the provisions of the 1981 Act concerning naturalization. Henceforward a person applying for naturalization must pass a test demonstrating a sufficient knowledge of English (or Welsh or Gaelic). They must also demonstrate a knowledge of life in the United Kingdom. There is now a citizenship ceremony modelled closely on that used in Canada, including taking an oath of allegiance. (In the presence of the Prince of Wales, the first such ceremony was held in February 2004.) Persons obtaining citizenship through marriage will also have to fulfill language and knowledge requirements. The 2002 legislation also provides for the deprivation of citizenship under certain conditions. ${ }^{2}$

Britain recognizes dual citizenship, and accords some privileges to Commonwealth citizens and to European Union members. Commonwealth citizens who have a parent or grandparent who was born in the UK are permitted to enter, reside in, and work in Britain without special permits. In May 2004, the European Union was expanded to include a number of former eastern and central European states. The number of countries whose members are free to move and live anywhere in Britain and Europe was increased from fifteen to twenty-five, with other countries possibly becoming eligible at a later date. ${ }^{3}$

Citizens of the United Kingdom and other EU countries have the following rights:

- freedom of movement and residence on the territory of member states;

- the right to vote and to stand for office in local elections and the European Parliament elections in the state of residence;

- the right to diplomatic protection by the diplomats of any EU state in a third country; and

- the right to petition the European Parliament and the possibility of appealing to an ombudsman.

As noted by Castles and Davidson, ${ }^{4}$

The first striking characteristic of the new citizenship is how it severs citizenship rights from national belonging. Already there is a push to extend the right to vote to national elections as well as local and European elections. It thus goes further than does the multicultural citizenship of nation-states, in which there is still a residue of the old demand for national belonging.

The prospect of ten new members joining the European Union on 1 May 2004 caused concern in the tabloid press 
with exaggerated estimates of the numbers who would seek entry to the UK in search of jobs and social benefits. The opposition Conservative Party, together with the minority British National Party and the UK Independence Party (which is critical of Britain's involvement with Europe) all called for stricter controls to prevent abuse of the immigration system. There was particular hostility to the possible influx of Roma from eastern and central Europe.

\section{Immigration Controls}

Entry to Britain, including the need for a visa, length of stay, permission to work, and the right to permanent residence are subject to complex regulations that have changed over time. The earliest controls were introduced with the Aliens Act 1905, which was designed mainly to limit the entry of Jews suffering persecution in eastern Europe at that time. The Aliens Restriction Act of 1914, as amended in 1919, introduced passports. Immigration from Commonwealth countries remained open until 1962, when new laws limited immigration from the Indian subcontinent and from the Caribbean. Further restrictions came into force in 1968, at the time of the East African (Uganda and Kenya) crisis concerning Asian residents in that region. A quota system was introduced to limit numbers admitted annually. The nationality legislation of 1981, to which reference has been made, served to limit the right of entry for former British subjects in dependent territories, and made it possible to limit the numbers of Hong Kong Chinese who could emigrate to the UK when the colony was incorporated into mainland China in 1997.

Due to the growth in tourism, business travel, and asylum applications, control of borders has become a serious concern for the UK government, particularly since the opening of the Channel Tunnel. In the year 2002, there were approximately 89.3 million entries to the country. The majority of these were UK or EU citizens. British citizens carry an EU passport which enables them to travel freely throughout the European Economic Area (EEA). By the same token, EU nationals from other countries can enter Britain freely and work there. Visas are required before admission to the UK by residents in most other countries outside of the EU. There are 165 UK visa sections around the world. In 2002, an estimated 12.6 million entrants were from outside the EEA; the majority of these were tourists or business travellers admitted temporarily. Approximately 369,000 students were admitted. There were 120,115 work permit holders and their dependents. In 2002, 50,360 people were refused entry at the port, including 3,730 asylum seekers. ${ }^{5}$

With the prospect of increased immigration from new EU countries after 1 May 2004, the government announced a system of registration of those from the new member states who were seeking employment in the UK. However, this was criticized as discrimination against new EU members, since no permits or registration applied to existing EU members. A scandal arose in March 2004 when it was revealed that, without ministerial authority, officials had been issuing work permits, or permission to start a business, to people already in the UK from the EU countries about to be admitted who would otherwise have been deported as illegal immigrants. Earlier, the press had noted the absurdity of deporting people from eastern and central Europe who would shortly have a legal right to return to Britain.

\section{Refugees and Asylum Seekers}

The debate over immigration policy in Britain became heated in the late 1990s and early in the twenty-first century, mainly because of concerns arising from the growth in numbers of asylum seekers. A government policy statement in 1998, "Fairer, Faster and Firmer," and the Asylum Act 1999 which followed, endeavoured to reduce delays and backlogged applications for asylum. It also introduced a system of "vouchers" for welfare benefits, which were at a lower rate than that for British citizens and stigmatized the recipients. Asylum seekers were dispersed across the country. Following a government report, Secure Borders, Safe Haven: Integration and Diversity in Modern Britain, in 2002, other measures were introduced to deter applications and penalize carriers who, knowingly or not, brought illegal immigrants into the country. However, these measures failed to stem the flow of people applying for asylum, whether they had entered the country legally or illegally. Acceptance rates fluctuated according to the nationalities involved and the global crises at the time, averaging 41 per cent over the decade 1993-2002, but only 19 per cent received full Convention refugee status, the remainder being given "Exceptional Leave to Remain." With growing numbers of asylum applicants "in limbo" because they were not allowed to work or settle permanently in Britain, various measures to reduce delays in processing and remove the backlog in applications were adopted. In 1998, indefinite leave was given to 10,000 cases and a further 20,000 received “special consideration." In 2003, 15,000 families, who had been in the country more than three years without a final determination of their status, were give indefinite leave to remain in the UK.

In the year 2002, the UK received 84,130 applications. The leading countries of origin were Zimbabwe, Afghanistan, Somalia, and China. Out of those processed, only 10 per cent were initially approved for Convention refugee status and a further 24 per cent were given a temporary 
U.K. Asylum Decisions 2000 - 2003

(excluding dependants)

Number of Principal Applicants

\begin{tabular}{|c|c|c|c|c|}
\hline & 2000 & 2001 & 2002 & 2003 \\
\hline Application s Received & 80,315 & 71,025 & 84,130 & 49,370 \\
\hline Decisions & 101,645 & 120,950 & 83,540 & 64,605 \\
\hline Granted asylum & 10,605 & 11,450 & 8,270 & 3,880 \\
\hline $\begin{array}{l}\text { Granted Exceptional Leave } \\
\text { to Remain }\end{array}$ & 11,475 & 20,190 & 20,135 & 7,107 \\
\hline Refused Asylum and ELR & 67,910 & 89,310 & 55,130 & 53,510 \\
\hline $\begin{array}{l}\text { Appeals Received by Appellate } \\
\text { Authority }\end{array}$ & 46,190 & 74,365 & 51,695 & 79,575 \\
\hline Appeals determined & 19,395 & 43,415 & 64.405 & 81,725 \\
\hline Appeals allowed & 3,340 & 8,155 & 13,875 & 16,070 \\
\hline $\begin{array}{l}\text { Total granted asylum, } \\
\text { ELR or appeal allowed }\end{array}$ & $35,7405^{\star}$ & 39,795 & 42,280 & $27,057^{\star}$ \\
\hline $\begin{array}{l}\text { Removals and voluntary } \\
\text { departures }\end{array}$ & 8,980 & 9,285 & 10,740 & 12,490 \\
\hline
\end{tabular}

* Includes some granted asylum or ELR, under backlog criteria.

Source: Asylum Statistics (United Kingdom, Home Office, 2003).

residence status (i.e., exceptional leave to remain). In that year, there were 64,405 appeals determined, of which 22 per cent were allowed to stay. Overall in 2002, 50 per cent of those about whom final decisions were made were allowed to remain in the UK, on a permanent or temporary basis. Excluding dependents, there were 10,740 asylum removals, including voluntary departures. ${ }^{6}$ The number of applications fell to 49,370 in 2003; altogether 64,605 initial decisions were made (removing some of the backlog); 6 per cent of these were given refugee status and 11 per cent either exceptional leave to remain or one of two new categories: Humanitarian Protection or Discretionary Leave. ${ }^{7}$ In 2003, 81,725 appeals were heard, of which 20 per cent were allowed. Overall, 42 per cent of those about whom decisions were reached were allowed to stay. Somalia had the largest number of successful applicants; 1,660 were given refugee status and a further 550 exceptional leave to remain or temporary protection. Excluding dependants, 12,490 failed asylum seekers were removed, or required to depart, in 2003. When dependents are included the number was 17,040 persons. Leading countries of failed asylum seekers were Serbia and Montenegro, the Czech Republic, Afghanistan, Romania, and Albania.

In February 2003, referring to new legislative and administrative measures designed to deter applications for asylum, the Home Secretary stated: ${ }^{8}$

These measures are not yet fully reflected in the statistics, although we are seeing some early indications of success with a fall in applications from Zimbabwe, where we have imposed a visa regime. There are also fewer from the Czech Republic and Poland which contributed to significant increases in the middle of the year until we introduced the list of countries from which claims would be presumed manifestly unfounded....

We have always said that we expect the measures introduced as part of the NIA Act to build over time. Those measures are now in place, but their full impact will not have been felt over the latter part of the year. The figures published today give us a clear benchmark to measure what we expect will be very significant progress over the next six months and indeed the coming years. 
The popular press continued to represent most asylum seekers as bogus and, after September 11,2001, linked them to terrorist threats. Human rights questions also came to the fore early in 2003 when the UK government, in consultation with other EU countries, explored the possibility of deporting many asylum seekers to "safe havens" on the borders of the countries from which they had fled. It was alleged that the cost of doing so would be less than providing for them in the UK. Deportation of failed asylum seekers to countries where they might face torture or death threats was also considered, despite the breach of UN and EU human rights conventions that this would entail. The following is a summary of the concerns expressed by the UNHCR: ${ }^{9}$

- "Safe third country" criteria are below the standard needed to ensure effective protection'

- Lack of minimum protection standards at borders

- The denial of right to remain while appeals are heard

- Accelerated procedures will threaten fair hearing

- Permissible grounds for detention not limited or defined

- Restricted access to legal assistance and representation

- Absence of gender sensitivity procedures

\section{Recent Changes to the U.K. Asylum and Immigration Appeals System}

New legislation, introduced in November 2003, gave authorities the power to tag asylum seekers electronically, rather than place them in detention, when their applications have been rejected. The Home Secretary proposed to adopt a new kind of tag, employing satellite technology to pinpoint the wearer's location, to be used within twelve to eighteen months. People who would be tagged would mostly be unsuccessful asylum seekers, but would also include those who had no justifiable claim and who were waiting removal..

New measures will also reduce asylum seekers' access to an appeals process more severely than had previously been expected. The UK Government proposes to replace the current two-tier structure with a single appeal to a new single-tier tribunal, the Asylum and Immigration Tribunal, headed by a president. The proposed abolition of the former Immigration Appeal Tribunal would limit access to the higher courts. However, proper judicial review is a necessary check on illegality, breaches of natural justice, and abuse of powers. Lord Chief Justice Wolf condemned the proposal, describing it as "fundamentally in conflict with the rule of law." Following this criticism the clause was amended. ${ }^{10}$

Measures will also be introduced to ensure that asylum seekers who arrive without valid documents or a good explanation, or who have travelled through a safe third country and/or applied for asylum late, would have the credibility of their claim reduced. Two new criminal offences are proposed for being undocumented without good explanation and failing to co-operate with re-documentation. There is also a proposal to require carriers to take copies of passengers' identity documents before they travel.

These measures will penalize genuine refugees and expose them to risk of prosecution. Increased border controls, including the extension of visa requirements to refugeeproducing countries, carrier liabilities, and juxtaposed controls, have reduced options for a safe and legal transit to the EU for the purpose of asylum. The right of appeal, on Convention and European Convention on Human Rights grounds, for individuals being removed to a "safe third country," will be limited. In negotiations over the draft EU Directive on asylum procedures, the UK sought a definition of "safe third country" that would have allowed transfer to a country which the asylum seeker had no link with and had never set foot in. Asylum seekers could be removed to a "zone of protection" for processing a claim. In negotiations over the EU Directive on asylum procedures, which came into force in 2004, the UK sought unsuccessfully to follow the Australian precedent to have asylum seekers removed to a "zone of protection" for processing the claim outside the country. The UK Government also proposed to remove support from families required to leave the UK. Support under Section 20 of the Children Act 1989 will not be available to asylum-seeking families. In some circumstances, children of failed asylum seekers will be separated from their families, which could be a further breach of human rights.

The new Asylum and Immigration Act, which received Royal Assent in July 2004, will also give immigration officers new powers to arrest people for offences that fall outside normal immigration crimes. They will be able to arrest without a warrant on suspicion of bigamy, fraud, and theft. The government has also announced plans to limit asylum seekers' access to legal aid, and will restrict access to the High Court, for appeal against deportation. Other recent UK Government actions designed to tackle the perceived widespread abuse of the asylum system include:

- radical reform through the Nationality, Immigration and Asylum Act, including: setting up a list of countries presumed to be safe, whose nationals have no right of appeal in the UK; restrictions on benefits for asylum seekers; and a clampdown on social benefit shopping;

- ending of "exceptional leave to remain" and replacing it with a new narrower category of humanitarian protection;

- the sealing of the Channel Tunnel at Coquelles and Fréthun in France; 
- closure of Sangatte (i.e., the French refugee centre; 67,000 people had passed through its gates);

- the introduction of freight searching and UK immigration controls in France and along the European coast as needed;

- stopping asylum seekers working and stepping up action on illegal working;

- imposing a visa regime for Zimbabwe; and

- introduction of universal identity cards.

The Home Office announced that a six-month trial of new "high-tech" passports would lay the foundations for a compulsory identity card scheme. A pilot scheme will involve 10,000 volunteers receiving personalized "smartcards" containing biometric information - initially, a digital image of their faces based on passport photographs. The immigration minister stated it was a preparation for compulsory identity cards. It was claimed that linking biometric data to a national database would help to prove eligibility for services, preventing identity fraud, immigration abuse, illegal working, and organized crime. Concern with these issues was intensified in February 2004, when nineteen Chinese immigrants were drowned picking cockles at night in Morecombe Bay. Investigative journalists subsequently drew attention to the widespread employment by "gangmasters" of illegal immigrants, including failed asylum seekers, in the agricultural and construction industries.

\section{Entitlement to Services}

While the United Kingdom itself participates in the broader political unit of the European Union, it has also devolved powers, including those relating to education and social services, to Scotland and Wales, which have their own legislatures. This has led to some variation in social policies. Further differences exist between the UK and other EU countries. In the context of contemporary "welfare societies," dual citizenship and freedom to live and work in other countries raises questions of entitlement. Education, health services, housing, unemployment, and other social benefits, including children's allowances and old-age pensions, may be paid for out of taxation or compulsory insurance. Theoretically, no-one should be destitute and homeless when living in a contemporary advanced society with a developed welfare system, whether they are citizens or not. Bloch and Schuster note that: "All legally resident migrants in Western European states are in principle entitled to most of the welfare provisions of other citizens. However, the welfare state is a site of both inclusion and exclusion." ${ }^{11}$ In some cases, reciprocal arrangements may be made between countries that have similar systems. Periods of working and paying taxes in one country may be counted toward eligibility for benefits in another. In practice, most countries fall short of this ideal. Much of the resentment against immigrants and asylum seekers concerns their alleged dependence on state support and "jumping the queue" for housing and other entitlements. When a xenophobic fear of "foreigners," racism, and religious prejudices are added to terrorist threats, however unfounded, a climate of hate is created that right-wing extremist and nationalist parties are able to exploit. This has been clearly the case in Britain where the popular press has stirred up resentment against asylum seekers, and immigrants in general, and the extreme right-wing British National Party has succeeded in winning seats in some local elections.

Following the Immigration and Asylum Act, 1999, the UK Government created a National "Asylum Seekers Support Service” which assumed responsibilities for housing and welfare, previously undertaken by local authorities. A system of vouchers, of lower value than regular welfare benefit rates, replaced monetary support, and also made the asylum seekers more visible and open to expressions of abuse. The Nationality, Immigration and Asylum Act, 2002, not only amended British nationality legislation, but, under Section 55, it also removed the entitlement to any financial support for those who made a claim for asylum "in country," i.e., after being allowed to enter or entering in a clandestine manner. Only those actually making an asylum claim at the border (mainly airports) and having a prima facie case would be able to claim any social benefits. This would disqualify the two-thirds of all asylum seekers who filed their applications after arrival in Britain. The rule was meant to have a deterrent effect and make Britain seem less of a "soft touch" to potential refugees and economic migrants. In February 2003, this regulation was subject to a judicial appeal on human rights grounds. In some cases financial support and housing had been refused to people who had been in the country less than twenty-four hours. A High Court judge held that this was in breach of European human rights legislation. Subsequently, the government amended the rule to "as soon as reasonably practicable." However, research conducted by the Refugee Council showed that many asylum seekers were forced into homelessness and begging as a consequence of the enforcement of the rule. ${ }^{12}$

Other controversial issues concerned the detention of newly arrived asylum seekers in secure accommodation which ranged from former army camps to hotels. Local residents expressed strong opposition to these plans. While waiting for the asylum verdict, applicants and their families were dispersed from London and the southeast of the country, where they had been concentrated, to public housing in northern towns. Applicants whose cases were rejected were housed in prison-like accommodations run by private 
contractors. There were many complaints about conditions and a notorious incident in which a custom-built centre burned down, following a protest organized by some of the inhabitants. At the end of 2003, 80,120 asylum seekers were receiving welfare under the National Asylum Support System, including 49,760 who were housed. In December 2003, 1,285 asylum seekers were in detention, and in the calendar year 2003, 17,040 persons, including dependants, were deported. ${ }^{13}$

\section{Conclusion}

The contemporary world system may be a "global village" in many respects but it is one in which, to use an Orwellian phrase, some are "more equal than others." Citizenship accords special rights and privileges but those may overlap, or conflict with, more general human rights as defined in the Universal Declaration of Human Rights, the European Human Rights Code, the UN Refugee Convention, the I.L.O. Conventions on Migrant Workers, and other treaties that a country enters into. Inequalities, within and between countries and continents, become more evident and less tolerable as a result of globalization. The recently increased threat of terrorism has led to heightened levels of military security, as well as new powers to the police, immigration authorities, and the courts, that threaten fundamental freedoms and human rights.

Globalization has brought about inherent contradictions within the world system. New forms of social exclusion have occurred. ${ }^{14}$ Ease of travel and communication, together with worldwide trade, have brought people closer together and made it easier to enjoy the benefits of dual, or multiple, citizenship together with fuller participation in the political systems that transcend the boundaries of former "nation-states." However, this process has generated aspirations for self-determination by regional entities and ethno-religious minorities. It has also fuelled fear and insecurity, leading to heightened levels of prejudice, and sometimes violence, against visible minorities and "newcomers," irrespective of the legitimacy of their claims to full inclusion in the country they have chosen, or have been forced, to live in.. Britain's engagement in the war with Iraq exacerbates the fears that globalization had already generated. In turn this leads to a regression into jingoism, on the one hand, and protest against the war, on the other. As Falk states:

The idea of citizenship is increasingly applied to other political communities, supporting the notion of a European citizen and even a world citizen. One impact of globalization and the rise of regional political communities is to establish multiple identities and a non-exclusive sense of citizenship. War is a throw- back to simpler times of exclusivity, a tribal sense of passionate solidarity that is incapable of objectivity. ${ }^{15}$

Britain is experiencing the same contradictory forces as Canada, Australia, the United States, France, Germany, and other advanced industrial societies are experiencing in the face of globalization. While international trade and migration bring the countries of the world closer together, they also generate conflicting interests. Political and economic insecurities exacerbate prejudice against ethnic minorities and "foreigners," including those fleeing war or seeking protection from persecution. In turn, majorities and minorities alike have an ambivalent attachment to the wider society and a nostalgia for the sense of belonging to a more homogeneous community. The result is more "refugees in limbo" unable to find a safe haven.

\section{Notes}

1. For a guide to details of naturalization requirements see: $<$ http://94203.40/default.asp!pageid16>.

2. For details see: $<$ http://www.legislation.hmso.gov.uk/acts $>$.

3. Original members of the European Union are Belgium, Germany, France, Italy, Luxembourg, the Netherlands, Denmark, Ireland, the UK, Greece, Portugal, Spain, Austria, Finland, and Sweden. The European Economic Area (EEA) includes all EU members plus Norway, Iceland, and Liechtenstein. Those joining the EU on 1 May 2004 were Poland, the Czech Republic, Hungary, Slovakia, Lithuania, Latvia, Slovenia, Cyprus, Malta, and Estonia. Candidates for future membership include Romania, and Bulgaria.

4. Stephen Castles and A. Davidson, Citizenship and Migration: Globalization and the Politics of Belonging (London: Palgrave, 2000), 176.

5. For details see: Jill Dudley, Gill Turner, and Simon Woollacott, Control of Immigration: Statistics United Kingdom, 2002 (London: Home Office, 28 August 2003).

6. See: Tina Heath, Richard Jeffries, and Adam Lloyd, Asylum Statistics: United Kingdom 2002 (London: Home Office, 28 August 2003).

7. Exceptional Leave to Remain was replaced in mid 2003 by two new categories. Humanitarian Protection is defined as: "though not refugees would, if removed, face in the country a serious risk of life or person arising from the death penalty, unlawful killing or torture, inhuman or degrading treatment or punishment." Will be granted three years leave and then, if still in need of protection, may apply for settlement in the UK. Discretionary Leave is given to those who "do not otherwise qualify for leave. Periods of three years or less may be granted. After which a person will be able to apply for a further period of leave, but not for settlement."

8. See Home Office News Release Ref. 058/2003; for a critical commentary see: <http://www.refugeecouncil.org.uk/news/ feb2003/relea103.htm $>$. 
9. See: Directive on Minimum Standards on Procedures for Granting and Withdrawing Refugee Status, Aide Memoire (Geneva: UNHCR, 18 November 2003). In April 2004, the UNHCR expressed concern that new European Union legislation could lead to breaches of international law. The new EU Asylum Procedures Directive designates so-called "safe third countries" to which asylum seekers may be returned and introduces rules which allow countries to deport people before appeals are heard. Asylum seekers can be denied a hearing if they have passed through a so-called safe country, including any other EU member state. See: UNHCR News, 30 April 2004.

10. See "Top Judge Attacks Asylum and Legal Reforms," <http:// www.timesonline.co.uk> (accessed 3 March 2004). In the face of much criticism, the government withdrew the clause limiting access to the appeal courts during debate in the House of Lords, 15 March 2004. An administrative court will have oversight.

11. Alice Bloch and L. Schuster, "Asylum and Welfare: Contemporary Debates," Critical Social Policy 22, no. 3 (2002): 393-414.

12. See "The Impact of Section 55: Inter-Agency Partnership Survey of Asylum Seekers It Supports," Refugee Council report, February 2004; online: <www.refugeecouncil.org.uk $>$ (accessed 3 February 2004).

13. For demographic details see: <http://www.homeoffice.gov. uk/rds/pdfs2/hosb803.pdf $>$.

14. See Anthony H. Richmond, "Social Exclusion: Belonging and Not Belonging in the World System," Refuge 21, no.1, (November 2002): 40-48, and "Socio-Demographic Aspects of Globalization: Canadian Perspectives on Migration," Canadian Studies in Population 29, no.1 (2002): 123-49.

15. Richard. Falk, "Testing Patriotism and Citizenship in the Global Terror War," Worlds in Collision: Terror and the Future of Global Order, ed. K. Booth and T. Dunn (London: Palgrave, 2002), 32.
Anthony H. Richmond, F.R.S.C., is Emeritus Professor of Sociology and Senior Scholar, Centre for Refugee Studies, York University, Toronto. 